ПКЗ - Писцовая книга Заонежской половины Обонежской пятины А. В. Плещеева и подьячего С. Кузьмина 1582/1583 г. // История Карелии в XVI-XVII вв. в документах. Т. 3 / ред. И. А. Чернякова, К. Катаяла. Петрозаводск ; Йоэнсуу, 1993. C. $35-341$.

IMS - Inkeroismurteiden sanakirja / toim. R. E. Nirvi. Helsinki, 1971 (Lexica societatis Fenno-ugricae; XVIII).

VKS — Vadja keele sxnaraamat / peatoim. V. Hallap. T. 1-7. Tallinn, 1990-2011.

DOI 10.31168/7996-2700-3.113

\author{
Петр Соботка \\ Торунь, Польша \\ psobotka@umk.pl
}

Университет Николая Коперника

\title{
Этимология и смысловое развитие севернославянских коннекторов, образованных от местоимений*
}

Объектом изучения являются севернославянские коннекторы. Под коннекторами понимается группа лексем, имеющих соединительную функцию; это союзы, относительные местоимения, некоторые предлоги или частицы и т. д. Коннектор связывает предложение или его часть с тем, что ему предшествует. Термин севернославянские языки объединяет западнославянские и восточнославянские языки. Они противопоставлены южнославянским языкам, которые в IX в. были отделены от других групп славянских языков в результате вторжения мадьяр на территорию Среднедунайской низменности, что обусловило самостоятельное языковое развитие двух частей общеславянского ареала. Об этом разделении свидетельствуют различные реализации фонетических процессов, а также результаты грамматикализации, что является наиболее значимым в контексте настоящего исследования.

\footnotetext{
*Научная работа выполнена в рамках гранта Министра науки и высшего образования РП под названием «Национальная программа развития гуманитарных наук» на 2018-2023 гг., номер проекта 11Н 17006685.

(C) Соботка П., 2019
} 
Индоевропейские местоимения довольно легко трансформировались в наречия (ср. польск. nijak $)$, предложные наречия (польск. bodaj), союзы (чеш. totiž), частицы (словац. jistotni), артикли (ср. франц. le, la из лат. ille, illa; нем. der, die, das; болг. -mъ, -ma, -mo), словообразовательные (польск. -owaty) и флективные морфемы (ср. праслав. *-jb, *-ja, *-je). Грамматикализация местоимений определяется четырьмя механизмами, которые преобразуют местоимения в другие части речи:

1) семантическая деривация, ср. праи.-е. *h, ió-> праслав. *jb; праслав. *tu > польск. tu, рус. туm, ср. польск. Kogo by tu pożré́... [NKJP];

2) словосложение, ср. рус. потом < * ро $+*$ tomь, по(э)тому <

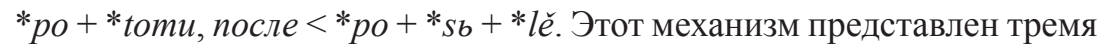
основными типами: «местоимение + местоимение» (ср. праи.-е.*id-tó- > праслав. *jbst-> чеш. na-jisto); «предлог + местоимение» (ср. чеш. nadto, pritom); «местоимение + частица» (ср. чеш. $k d y z$, již);

3) словообразовательная деривация, и особенно суффиксация, например праи.-е. ${ }^{*} k^{u} \delta^{-} / *^{u} k^{\prime}->$ лат. qui-d (ср. праслав. $* k-d-$ ), польск. g-dzie, чеш. v̌̌-ak, jedn-ak и т. д.;

4) образование параллельных конструкций и редупликация, ср. польск. toto, польск. to a to, tu i tam, ni stqd, ni zowqd, pус. так и сяк.

В докладе рассматривается историческое развитие славянских коннекторов, образованных от предлога и указательного местоимения, например польск. zatem 'следовательно' от zatym 'за этим'. Из таких сложений в зависимости от языковых и внеязыковых факторов образуются союзы или частицы (см. табл.).

\begin{tabular}{|c|c|c|c|}
\hline & Русский & Польский & Чешский \\
\hline Союз & $\begin{array}{l}\text { (как) будто, из-за того } \\
\text { что, кроме того что, } \\
\text { оттого (что), после } \\
\text { того как, потому (что), } \\
\text { затем (что (бь)), зато }\end{array}$ & $\begin{array}{l}\text { dlatego, nato- } \\
\text { miast, ? przeto, } \\
\text { toteż }\end{array}$ & $\begin{array}{l}\text { proto }(\check{z} e), \text { prestože, } \\
\text { zatímco, zato }(\mathrm{cp} . \\
\text { также: anžto, jakožto, } \\
\text { ježto, kdežto, kdyžto, } \\
\text { přičemž) }\end{array}$ \\
\hline Частица & & $\begin{array}{l}\text { nadto, ponadto, } \\
\text { poza tym, przeto, } \\
\text { przy tym, zatem }\end{array}$ & $\begin{array}{l}\text { beztoho, kromé toho, } \\
\text { nadto, potom, pritom, } \\
\text { totiž, zato }\end{array}$ \\
\hline
\end{tabular}

Данные коннекторы можно разделить на два основных типа: de dicto и de re. Первоначально местоимение в коннекторах de dicto 
играло роль местоимения с референцией к предложению, а в коннекторах de re выступало в качестве анафорического местоимения (с референцией к объекту, о котором идет речь), ср. следующие примеры:

- чеш. «Slyšeli jste, co jest řečeno dávno starým: Oko za oko a zub za zub. Ale já vám nadto pravi: Neprotiviti sě zlému»;

- ст.-рус. «С тъхъ угодеи, которые написаны в Двинскихъ писцовыхъ книгах, оброчныхъ денегъ взять нъ на комъ, потому Кулисково посаду крестьяне во 149-мъ году разбрелись врознь от збору нашимъ ратнымъ людемъ на жалованье».

Эта дифференциация привела к сегодняшнему различию (хотя и нечеткому) между связывающими частицами и союзами. Связывающие частицы, образованные сложением предлога и местоимения, развивались гораздо более продуктивно в западнославянских языках, чем в восточнославянских. Мы полагаем, что это может быть связано с влиянием латыни на западнославянские языки (а не греческого на восточнославянские) как литургического языка-источника. Древнеславянский материал показывает, что местоименные формы на *to этимологически образованы от местоимений, имеющих различные функции. По-видимому, это основная причина, по которой из них формируются разные части речи. Функция предлога в этих сложениях также интересна. Он тоже грамматикализуется и в сложении выполняет соединительную роль - связывает объект, о котором говорится в предложении, с содержанием de re или одно содержание с другим. Эта связь может «прочитываться» как вертикальная (ср. сверх того), горизонтальная (ср. по + тому, за + тем), внешняя (ср. кроме того), внутренняя (ср. в том).

NKJP — Narodowy korpus języka polskiego. URL: http://nkjp.pl. 